\title{
Examining upper echelons managers' characteristics on financial restatements
}

\author{
Syarifah Saffa' Najwa Tuan Besar \\ Faculty of Accountancy, Universiti Teknologi $M A R A$ \\ Malaysia \\ sysaffanajwa@gmail.com
}

\section{Mazurina Mohd Ali}

Faculty of Accountancy, Universiti Teknologi $M A R A$

Malaysia

mazurina@salam.uitm.edu.my

\section{Erlane K Ghani}

Accounting Research Institute, Universiti Teknologi $M A R A$

Malaysia

erlanekg@salam.uitm.edu.my

Abstract. This study examines the effect of manager's characteristics on financial restatements among Malaysian public listed firms. Manager's characteristics in this study refer to the Chief Executive Officer's (CEO) and Chairman of Audit Committee's (CAC) characteristics in an organisation. Using content analysis on 750 annual reports of 150 public listed firms in Bursa Malaysia, this study analyses the relationship between $\mathrm{CEO}$ and CAC's characteristics and financial restatements. The results show that only CEO's characteristics in terms of educational and functional background significantly affect the financial restatements of the listed firms but the results are positive. The implication of this study is that more thorough recruitment of top managers is needed as their specific characteristics affect the financial restatement decisions. This study provides new data for the regulatory bodies which can be used further in setting rules and regulations in relation to managers for preventing aggressive financial restatements among the public listed firms.

Keywords: Financial restatement, Upper Echelon theory, managers' characteristics, listed firms, Malaysia.

JEL Classification: L25, M41 


\section{INTRODUCTION}

Financial statement serves as a medium for firms to disseminate related and useful information to all stakeholders. The issuance of a sound financial statement by top management is important since investors rely on these financial statements while evaluating future cash flows and other conditions. However, the discovery of high-profile corporate scandals such as that with Enron and WorldCom in the United States provides indication that financial statements issued by firms do not necessarily represent true and fair view. That is, there are firms that tend to practice financial restatement. Financial restatement refers to the process of reviewing and altering errors found in the formerly issued financial statement that does not comply with the Generally Accepted Accounting Principles (GAAP) (Abdullah \& Mohd Nasir, 2010). A number of financial restatement cases has occurred caused by quite reputable public-listed firms. This, in its turn, led to elimination of billions of dollars on the formerly reported earnings. Due to this scenario taking place, concerns were raised on the credibility and reliability of corporate financial disclosure as such. In the United States alone, there have been about 2,705 cases of financial restatement occurring from January 1997 until June 2006 (GAO, 2001; GAO, 2002).

Despite the economic consequences of financial restatement, the number of financial restatement cases have kept only increasing. As seen in the 2014 Financial Restatement Review conducted by the Audit Analytics, the number of financial restatement cases have been reported to increase up to $76 \%$ in the past eight years (2007 to 2014). Such scenario were supported by prior studies that found financial restatement cases increasing up to 1,795 in 2006, thus tripling the number of 475 financial restatements previously reported back in 2003 (Plumbee \& Mason, 1984). Therefore, the rise in financial restatement cases has drawn the attention of stakeholders, especially investors, as well as researchers and general public too.

Although financial restatement is meant to safeguard the stakeholders' interest by providing information that caters for users of financial statement, managers may use this practice as an opportunity to manipulate the financial statement despite the reporting requirement been mandated by the accounting standards. Thus, in order to prevent such practice among managers, the "tone at the top" culture should be embedded within organisations. Managers' characteristics such as age, functional track and education background may also play their role in mitigating the occurrence of financial restatements. Managers should thus be more proactive while in performing their duties and responsibilities. Managers are also responsible for encouraging their subordinates to behave ethically too (Hambrick \& Mason, 1984).

This study aims to examine whether managers' characteristics influence financial restatement among the public listed firms. The findings of this study would shed some light for both regulatory bodies and firms on the influence of managers' characteristics on effective design of corporate governance and also on the issue of managers' compensation relative to their performance evaluation.

The remainder of the paper is organised as follows. Section 2 provides the literature review and Section 3 presents the hypotheses' development. This is followed by Section 4 describing the research design employed in this study. Section 5 presents and discusses the empirical results. Section 6 concludes this study.

\section{LITERATURE REVIEW}

\subsection{Financial Restatements Studies}

Financial restatement signifies material misstatements and fraudulent financial reporting (Hasnan, Abdul Rahman, \& Mahenthrian, 2008). The restated financial statements reflect ambiguity of financial information disclosure. It portrays a catastrophic failure in an organisation's governance system which is 
often under the control and authority of an organisation's management (Hasnan, Abdul Rahman, \& Mahenthrian, 2008; Kimbery, 2013). The United States General Accounting Office (GAO) (2002) indicates that the incidents of financial restatement often occur when there is a deliberate misstatement of financial accounting information in the company's financial statements. GAO (2002) further states that auditors and authorities would often manage to detect financial restatement upon reviewing the financial information formerly reported.

The features of financial restatement include the categories and causes in providing a full picture of the events of financial restatement. GAO (2002) identifies nine categories of financial restatement. The categories comprise of (1) acquisitions and mergers, (2) cost or expense, (3) research and development, (4) other, (5) reclassification, (6) related party transactions, (7) restructuring, assets or inventory, (8) revenue recognition and (9) securities related. Different countries may have different nature of financial market. Any practices related to financial restatement would fall under the different categories of financial restatement corresponding to the nature of financial market. This is evidenced in a study that found majority of the financial restatements cases reported in the United States fall under the eighth category namely, revenue recognition. In Malaysia, a study has documented 44 restatements cases from 2002 until 2005 (Abdullah \& Mohd Nasir, 2010). They found that most financial restatements are caused by improper treatment of costs or expenses.

A body of the accounting literature have examined the causes of financial restatement practices. Among the causes are internal errors and transaction complexity that offer opportunities for the managers to take advantage on the provision of the alternative reporting methods (Plumbee \& Yohn, 2010). There are studies that have shown a positive link between manager's incentive and financial restatement (Brick, Palmon, \& Wald, 2006). The management has the propensity to restate the company's earnings in order to improve share price as it directly benefits the managers who own share options. This circumstance reflects the conflict of interest between the managers and the shareholders since the managers are motivated to maximise their wealth instead of maximising the shareholders' wealth and interest. Such circumstance raises several significant questions on the nature of directors' compensation incentive.

The theoretical perspective that could explain the influence of management characteristics and their risk-taking propensity towards the occurrence of financial restatement is the Upper Echelon theory. This theory suggests that the attributes of managerial background are predictors of the outcomes; strategic choices and the level of organisational performance (Hambrick \& Mason, 1984). The managerial demographic characteristics have often been used as proxy due to the difficulties in measuring the management standards and values. Therefore, the managers' demographic characteristics serve as the core of the theory.

\subsection{Hypotheses Development}

Previous studies have shown that manager's age influence corporate growth (Hart \& Mellon, 1970; Child, 1974; Hambrick \& Mason, 1984). Corporate growth includes sales and earnings volatility of the firms. These studies provide some of the different traits between younger and older executives. Older managers seem to be less able to grasp new ideas (Child, 1974), an indication that their characters make them less adaptable to new environment. Older managers are also reluctant to rely on new technologies. Therefore, older executives seem to be more of a risk averse in which they would avoid any actions that could jeopardize their financial security Carlsson and Karlsson (1970). In contrast, younger executives have contradicting characters to the older executives (Hambrick \& Mason, 1984). Younger managers prefer risky strategies and more adjustable to the unfamiliar environment. Since financial restatements often involving complex tasks that are related to inflating the firms' financial condition, younger CEOs 
and CACs would likely to practice financial restatement more compared to the older CEOs and CACs. Thus, the following hypotheses are developed:

H1a. There is a negative relationship between the age of CEO and financial restatements.

H1b. There is a negative relationship between age of CAC and financial restatements.

Executives' occupational background is one of the predictors for corporate actions and strategic choices (Hambrick \& Mason, 1984; Hambrick, 2007). The influence of management's functional track on a company's growth and performance (Hambrick \& Mason, 1984). The choice of strategies taken by the management could portray their functional area and consequently, influence their decisions. Managers' functional track is divided into two categories namely, throughput function and output function (Hambrick \& Mason, 1984). These two functions have different attributes whereby generally, the output function is associated with risk and uncertainty (Gupta,1984; Ali \& Taylor, 2014), whilst throughput function is associated with managers being much more conservative in terms of the strategies implemented and level of tolerance for uncertainty (Bamber, Jiang, \& Wang, 2010). Managers possessing throughput function seems to be more conservative and not likely for them to restate the firm's finances. This is consistent with prior studies that found financial restatement is often associated with risk and uncertainty elements. Thus, CEOs and CACs that possess output function would reflect their risk taking behavior and highly likely to be involved in financial restatement. Thus, the following hypotheses are developed:

H2a. There is a positive relationship between the output function of CEO and financial restatement.

$\mathrm{H} 2 \mathrm{~b}$. There is a positive relationship between the output function of CAC and financial restatement.

A group of studies have suggested that educational background does not influence organisational performance (Collins \& Moore, 1970; Hambrick \& Mason, 1984). Educational background refers to the knowledge and skills that an individual possess. A management with formal education appears to be more "self-made" executives as compared to a management with hands-on experiences (Collins \& Moore, 1970). In addition, highly educated managers are less innovative as they are likely to pursue short-term strategies rather than long-term strategic planning. Due to the uncertainty on the consequences of financial restatement, the CEOs and CACs may have the capability to evaluate the consequences of financial restatement based on their educational background. Thus, this study develops the following hypotheses:

H3a. There is a positive relationship between the level of education of CEO and financial restatement.

H3b. There is a positive relationship between the level of education of CAC and financial restatement.

A study has explained on the relationship between management's tenure and organisational performance (Hambrick \& Fukutomi, 1991). They suggest that different stages of tenure years by way of short-term tenure or long-term tenure would display different attitudes and behaviours towards their duties. Short-tenured CEOs may lack attentiveness in assessing significant matters and strategic risks of the company (Simzek, 2007). Of consequence, their performance in executing any strategic plans and ideas may be affected that led to minimum contribution to organisational growth and performance. Another group of studies however, argue that long-term tenured CEOs may result in greater risk 
avoidance as they tend to maintain their status quo (Miller \& Shamsie, 2001). Studies often view tenure years and age of an individual as the same (Hofstede, 1980). That is, managers with long-tenured years are often older in age and are likely to ignore risky strategies that would affect their financial securities. A study has also found that long-tenured managers are likely to ignore any changes as they are already complacent in their company (Hambrick \& Fukutomi,1991). As a result, long-tenured CEOs and CACs may unlikely be involved in financial restatement. Thus, this study develops the following hypotheses:

H4a. There is a negative relationship between CEO's tenure years and financial restatement.

H4b. There is a negative relationship between CAC's tenure years and financial restatement.

Ethnicity of a group is related to the cultural society (Hofstede, 1980). The linkage between societal values and institutional norms with an organisation's preference in accounting values and systems is explained in a study (Gray, 1998). The management is the decision-maker of a company that requires them to inculcate their cognitive bias and values in their decision-making process (Layton, 2008). In Malaysia, a multiracial society is dominated by two ethnic groups, namely, the Malays and the Chinese. The different preference of decision-making may be attributed by the norms and values of different groups. For example: the Malays appear to be less conservatism in matters related to compensation and political incentives compared to the Chinese that appear to be more conservatism (Ball, Robin,\& Wu, 2013). The Malays would be more likely to report higher quality of earnings as compared to the Chinese (Haniffa \& Cooke, 2005; Ball, Robin, \& Wu, 2013). For example: A study found that the Malay directors seem to be less secretive compared to non-Malay directors (Haniffa \& Cooke, 2005). Arguably, such findings could be applied to financial restatement study where there is a less tendency for the Malay executives to employ aggressive reporting method. Thus, the following hypotheses are developed:

H5a. There is a negative relationship between Ethnicity of CEOs and financial restatement.

H5b. There is a negative relationship between Ethnicity of CACs and financial restatement. The theoretical perspective that could explain the influence of management characteristics and their risk-taking propensity towards the occurrence of financial restatement is the Upper Echelon theory. This theory suggests that the attributes of managerial background are predictors of the outcomes; strategic choices and the level of organisational performance (Hambrick \& Mason, 1984). The managerial demographic characteristics have often been used as proxy due to the difficulties in measuring the management standards and values

\section{METHODOLOGY}

This study chose public listed firms on the Main Market of Bursa Malaysia. The Main Market includes six industries that are: consumer product, industrial product, properties, construction, plantation and trading, and service industry. Firms that have been classified under ACE Market and finance firms are excluded in this study due to different regulations and nature of business. One hundred and fifty firms are selected in this study due to their similarities in terms of industry, company size, same financial year-end, as well as similar industrial classification in Bursa Malaysia. Table 1 provides the sample distribution by industry. 
Sample Distribution by Industry

\begin{tabular}{|l|c|c|c|c|}
\hline \multirow{2}{*}{ Industry } & \multicolumn{2}{|c|}{ Number of restatement firms } & \multicolumn{2}{c|}{ Number of non-restatement firms } \\
\cline { 2 - 5 } & Total & $\%$ & Total & $\%$ \\
\hline Consumer Product & 9 & 12 & 9 & 12 \\
\hline Industrial Product & 20 & 26.7 & 8 & 26.7 \\
\hline Plantation & 8 & 10.7 & 6 & 8 \\
\hline Properties & 6 & 8 & 7 & 9.3 \\
\hline Construction & 7 & 9.3 & 25 & 33.3 \\
\hline Trading \& Service & 25 & 33.3 & 75 & 100 \\
\hline Total & 75 & 100 & & \\
\hline
\end{tabular}

This study performs its data collection using content analysis. The annual reports of the 150 public listed firms in Malaysia for 9 years (2007-2015) were collected. From the 150 public listed companies, 750 annual reports were used for this study. The purpose of the content analysis is to identify firms that under the category of 'financial restatements' and firms that are under the category of 'non-restatement firms'. This study follows the steps in a study (Abdullah \& Mohd Nasir, 2010) in identifying financial restatement of each company. The keywords of "restate", "restated", "restatement", "prior adjustment" are searched in each of the annual reports as to find the incidents of the restatement.

As a result, 75 firm-year firms are presumed to be involved in the event of the financial restatement. The procedure introduced by a study is used by using a control group for each restated company (Arthaud-Day, Certo, Dalton, \& Dalton, 2006). This control group represents the matching firms that are identified as non-restated firms. Upon completion of the content analysis, the number of firms selected for this study is 150. From the 150 firms, 75 represents the financial restatement firms and the remaining 75 represents the non-restatement firms.

In addition, this study adapts Hambrick and Fukutomi's (1991) and Haniffa and Cooke's (2005) variables in determining the background of the CEO and CAC. These variables include age, output function, level of education, tenure years and ethnicity. The information for these variables were also gathered through content analysis.

\section{Measurement}

\section{Dependent Variable}

Based on to Abdullah and Mohd Nasir (2010) and Ma (2011), the dichotomous variable is used as for the measurement of the financial restatement.

\section{Independent Variables}

The measurement of managers' demographic characteristics has been widely used in previous research such as Ali and Taylor (2014); Hambrick (2007) and Luo, Kanuri and Andrews (2013). While, competition is a proxy of barriers to entry and it is measured by total fixed assets (Ekramy \& Howard, 2013). Fixed assets usually are associated with the investment capital, and companies ensure the smoothness of their operation by managing their assets efficiently. Well managed assets reflect the competitive advantage of the companies (Okwo, Ugwunta, \& Nweze, 2012).

\section{Control Variables}


Consistent with the prior studies, the control variables in the restatements area of study consists of the firm size, leverage, auditor type and industry classifications (Haniffa \& Cooke, 2005; Ekramy \& Howard, 2013).

\section{Data Analyses}

Upon data completion, the data was analysed using Statistical Package for Social Science (SPSS, version 21). Apart from descriptive statistics, the Pearson correlation matrix and the logistic regression analysis were used to analyse the relationship between all variables towards financial restatement and CEO and CAC's characteristics.

\section{Model}

This study develops a model to achieve the research objectives of this study. The model offers an indication the effects of the background influences of the CEO and CAC on the financial restatements (Hambrick \& Fukutomi, 1991).

\section{Model:}

$$
\begin{aligned}
& \text { RES }=\beta_{0}+\beta_{1} \text { AGE_CEO }+\beta_{2} \text { AGE_CAC }+\beta_{3} \text { FUNT_CEO }+\beta_{4} \text { FUNT_CAC }+\beta_{5} \text { EDU_CEO } \\
& +\beta_{6} \text { EDU_CAC }+\beta_{7} \text { TEN_CEO }+\beta_{8} \text { TEN_CAC }+\beta_{9} \text { ETHN_CEO }+\beta_{10} \text { ETHN_CAC }+ \\
& \beta_{11} \text { SIZE }+\beta_{12} \mathrm{LEV}+\beta_{13} \mathrm{BIG} 4+\beta_{14} I \mathrm{INDS}
\end{aligned}
$$

Where;

Financial restatement, measured by a dummy variable 1 for restatement company and 0 for non-restatement company.

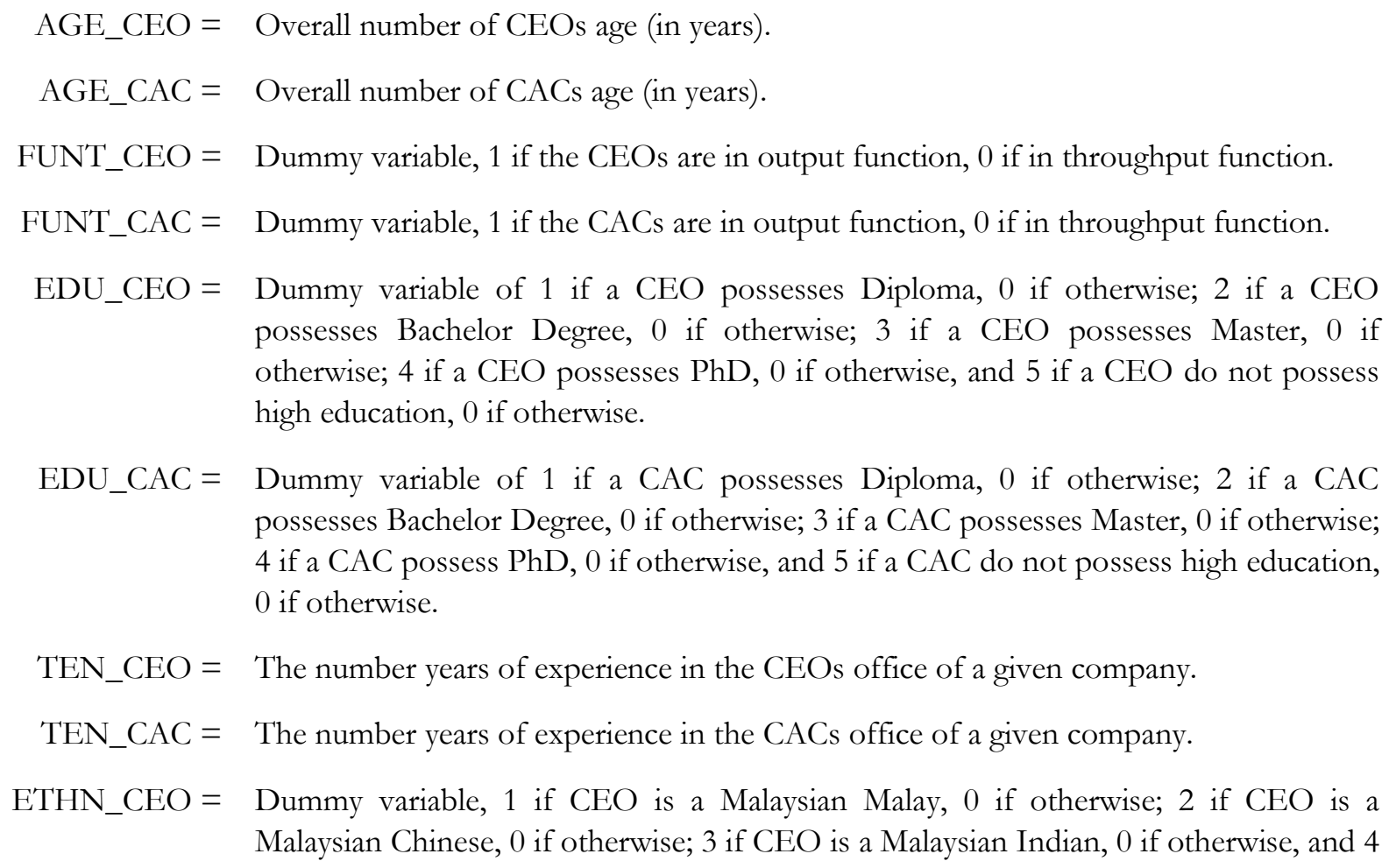
possesses Bachelor Degree, 0 if otherwise; 3 if a CEO possesses Master, 0 if otherwise; 4 if a CEO possesses $\mathrm{PhD}, 0$ if otherwise, and 5 if a CEO do not possess high education, 0 if otherwise.

EDU_CAC $=$ Dummy variable of 1 if a CAC possesses Diploma, 0 if otherwise; 2 if a CAC possesses Bachelor Degree, 0 if otherwise; 3 if a CAC possesses Master, 0 if otherwise; 4 if a CAC possess $\mathrm{PhD}, 0$ if otherwise, and 5 if a CAC do not possess high education, 0 if otherwise.

TEN_CEO $=$ The number years of experience in the CEOs office of a given company.

TEN_CAC $=$ The number years of experience in the CACs office of a given company.

ETHN_CEO $=$ Dummy variable, 1 if CEO is a Malaysian Malay, 0 if otherwise; 2 if CEO is a Malaysian Chinese, 0 if otherwise; 3 if CEO is a Malaysian Indian, 0 if otherwise, and 4 
if $\mathrm{CEO}$ is a Foreigner, 0 if otherwise.

ETHN_CAC $=$ Dummy variable, 1 if CAC is a Malaysian Malay, 0 if otherwise; 2 if CAC is a Malaysian Chinese, 0 if otherwise; 3 if CAC is a Malaysian Indian, 0 if otherwise, and 4 if $\mathrm{CAC}$ is a Foreigner, 0 if otherwise.

SIZE $=$ Firms' net sales.

$\mathrm{LEV}=$ Ratio of total liabilities to total assets.

BIG4 = Dummy variable, 1 if audited by Big 4 audit firms, 0 if otherwise.

INDS $=$ Dummy variables of 1 if the firm is in Consumer Product sector, 0 if otherwise; 2 if the firm is in Industrial Product sector, 0 if otherwise; 3 if the firm is in Plantation sector, 0 if otherwise; 4 if the firm is in Properties sector, 0 if otherwise; 5 if the firm is in Constructions sector, 0 if otherwise; and 6 if the firm is in Trading and services sector, 0 if otherwise.

\section{RESULTS AND DISCUSSION}

A descriptive statistics analysis was performed before testing the research hypotheses in this study. The analyses was performed to determine the age, tenure years, competition, company size and leverage. The results show that the age of CEOs ranges from 36 year to 87 years with the average age of 55 years. Meanwhile, the age of CACs ranges from 33 years to 84 years with the average age of 59 years. The results show that the majority of CEOs and CACs are in the 'throughput function' category. It is shown by an average 52.7 percent and 76 percent, respectively. Among 150 CEOs, 79 of them are with the throughput functions while remaining of 71 are in the output function. Similarly, the evidence shows that 114 out of 150 CACs are in the throughput function. Table 2 presents the results.

Table 2

Descriptive Statistics

\begin{tabular}{|l|c|c|c|c|c|}
\hline & $\boldsymbol{N}$ & Minimum & Maximum & Mean & Std. Deviation \\
\hline Age CEO (years) (AGE_CEO) & 150 & 36 & 87 & 54.84 & 9.449 \\
\hline Age CAC (years) (AGE_CEO) & 150 & 33 & 84 & 58.79 & 10.508 \\
\hline $\begin{array}{l}\text { Tenure CEO (years) } \\
\text { (TEN_CEO) }\end{array}$ & 150 & 1 & 45 & 12.57 & 8.942 \\
\hline $\begin{array}{l}\text { Tenure CAC (years) } \\
\text { (TEN_CAC) }\end{array}$ & 150 & 3 & 28 & 10.96 & 5.171 \\
\hline $\begin{array}{l}\text { Competition } \\
\text { (RM mil) (COMP) }\end{array}$ & 150 & 2.71 & 7.50 & 5.1908 & .71124 \\
\hline $\begin{array}{l}\text { Size (RM mil) } \\
\text { (SIZE) }\end{array}$ & 150 & 3.22 & 7.09 & 5.1333 & .63757 \\
\hline $\begin{array}{l}\text { Leverage (Ratio) } \\
\text { (LEV) }\end{array}$ & 150 & 0.00 & 2.85 & 0.3960 & 0.31732 \\
\hline
\end{tabular}

In respect of tenure years, the number years of experience in the office of a given company ranges from 1 to 45 years for CEOs and ranges from 3 to 28 years for CACs with the mean of 12.57 years and 10.96 years, respectively. This finding indicates that the CEOs in Malaysia have a longer tenure than CACs. The longer tenure specifies that some of the CEOs are also likely to be the founder of the firms. 
The average for competition, firm size, and leverage are RM 5.1908 million, RM 5.1333 million and 39.6 percent, respectively.

Most of the CEOs (40.7 percent) and CACs (41 percent) received a formal education and they hold Bachelor Degree, which come from various fields. Meanwhile, there are 50 CEOs and 49 CACs do not have any higher education by which most of their educational background is either primary or secondary level. Furthermore, with respect to the ethnicity, Malaysian Chinese CEOs represent an average of 62 percent of the sample of the firms. While, as for CACs, there is an average of 50 percent of the 150 firms are represented by Malaysian Malay.

\section{Managers' Characteristics and Financial Restatement}

Table 3 presents the correlation analysis results in examining the influence of managers' characteristics on financial restatements. As reported in the table, there is negative relationship between restatement and age as AGE_CEO; $r=-0.109$ and AGE_CAC; $r=-0.024$. These findings support H1a and $\mathrm{H} 1 \mathrm{~b}$ whereby the possibility for older $\mathrm{CEO}$ and CAC to engage in the financial statement is at low level. It is consistent with previous studies by which it indicates older CEOs and CACs are more risk adverse (Hart \& Mellon, 1970; Hambrick \& Mason, 1984). Older executives are also reluctant to involve in the aggressive practices as it can jeopardize their financial securities and career stability (Child, 1974). Thus, it displays that as executives grow older, they will not tolerate any aggressive accounting approach.

With respect to educational background, there is a positive relationship between restatements and education of CEOs; EDU_CEO $(r=0.170)$. This finding support H3a and indicates when CEOs have higher level of education, they tend to restate company's earnings if there are motivations to do such activities (Rosner, 2003). However, there is a negative relationship between financial restatements and CACs' education; EDU_CAC ( $r=-0.104)$ and it is contradict with the H3b.

In other words, CACs are less likely to do financial restatement regardless their level of education. This is because, the job scope of CAC itself do not compromise with the illegal practices within organisations. Audit committee are responsible to review any significant matters specifically financial issues that may have an impact on the organisation as well as the conformance to the accounting standards.

In respect to educational background, there is a positive relationship between restatements and education of CEOs; EDU_CEO $(\mathrm{r}=0.170)$. This finding support $\mathrm{H} 3 \mathrm{a}$ and indicates when CEOs have higher level of education, they tend to restate company's earnings if there are motivations to do such activities (Rosner, 2003). However, there is a negative relationship between financial restatements and CACs' education; EDU_CAC $(\mathrm{r}=-0.104)$ and it is contradict with the H3b. In other words, CACs are less likely to do financial restatement regardless their level of education. This is because, the job scope of CAC itself do not compromise with the illegal practices within organisations. Audit committee are responsible to review any significant matters specifically financial issues that may have an impact on the organisation as well as the conformance to the accounting standards.

There are also negative relationships between financial restatements and tenure years; TEN_CEO ( $\mathrm{r}$ $=-0.170)$ and TEN_CAC $(\mathrm{r}=-0.062)$. These results are consistent with the hypotheses for CEO's tenure years (H4a) and CAC's tenure years (H4b). This outcome indicates that the longer term of CEOs in the given office, the less likelihood for CEOs engage in the financial restatements. One of the reasons is that, CEOs are inclined to avoid any risky strategies, as they are risk adverse (Hambrick \& Fukutomi, 1991; Miller \& Shamsie, 2001). Similarly, with the circumstance for CACs by which long-tenured CACs does not take part in the incidence of financial restatements, as they are likely to avoid this practice due to their financial stability. Hence, the justification indicates that long-tenured CEOs and CACs tend to maintain 
their status quo (Miller \& Shamsie, 2001) which there are high likelihood for them to ignore any changes and may not consider the adoption of risky strategies as such ideas may affect their financial securities and career stability. Their responsibilities required them to become more committed towards organisations.

CEO's ethnicity also appears to have no relationship with the financial restatements (ETHN_CEO, r = .000). It means that the ethnicity of CEOs do not have any influence towards the occurrence of financial restatement. Meanwhile, the ethnicity of CACs shows negative relationship with restatements (ETHN_CAC, $r=-0.044$ ) which it supports H5b. It is expected that Bumiputera ethnicity does not have any association on the incidents of financial restatements and this result could relate to the descriptive of CACs in Table 3 in which majority of CACs are Malay. Prior studies suggested that preference in decision made reflect the value of certain group whereby the Bumiputera directors seem less secretive and they are likely to report high quality of earnings as compared to the Chinese (Ball, Robin, \& Wu, 2013). In addition, the Malay group ethnic often associates with the collectivism culture and Islamic faith (Hambrick \& Fukutomi, 1991). Therefore, it appears that there are fewer tendencies for Malay executives to employ the aggressive reporting method as the culture and faith had an influence on the decision taken on behalf of the organisation.

Table 3

Pearson Correlation Matrix

\begin{tabular}{|c|c|c|c|c|c|c|c|c|c|c|c|c|c|c|c|c|}
\hline & (1) & (2) & (3) & (4) & (5) & (6) & (7) & (8) & (9) & (10) & (11) & (12) & (13) & (14) & (15) & (16) \\
\hline (1) RES & & -.109 & -.024 & $-.170^{*}$ & -.062 & $.170^{*}$ & -.104 & $-.227^{* *}$ & -.031 & .000 & -.044 & .078 & .049 & .103 & -.013 & .000 \\
\hline $\begin{array}{l}(2) \\
\text { AGE_CEO }\end{array}$ & & 1 & $.250^{* * 1}$ & $.362^{* *}$ & .090 & $.257^{* *}$ & .109 & -.155 & -.119 & .142 & .057 & $.226^{* *}$ & .044 & -.149 & .051 & -.127 \\
\hline $\begin{array}{l}\text { (3) } \\
\text { AGE_CAC }\end{array}$ & & & 1 & $.332^{* *}$ & $.343^{* *}$ & -.009 & $.222^{* * *}$ & .023 & -.007 & .077 & -.080 & $.178^{*}$ & .053 & -.115 & .123 & .057 \\
\hline $\begin{array}{l}\text { (4) } \\
\text { TEN_CEO }\end{array}$ & & & & 1 & $.389^{* *}$ & -.013 & $.161^{*}$ & -.054 & .009 & $.255^{* *}$ & .038 & -.009 & -.139 & $-.178^{*}$ & .068 & -.101 \\
\hline $\begin{array}{l}\text { (5) } \\
\text { TEN_CAC }\end{array}$ & & & & & 1 & -.073 & .110 & .024 & .053 & .094 & .001 & .129 & -.015 & -.152 & -.012 & .077 \\
\hline $\begin{array}{l}\text { (6) } \\
\text { EDU_CEO }\end{array}$ & & & & & & 1 & -.106 & .007 & -.012 & $.193^{*}$ & -.023 & -.025 & .007 & .039 & -.093 & -.118 \\
\hline $\begin{array}{l}7) \\
\text { EDU_CAC }\end{array}$ & & & & & & & 1 & -.073 & -.025 & .081 & .116 & .133 & -.054 & -.109 & .128 & .127 \\
\hline $\begin{array}{l}(8) \\
\text { FUNT_CEO }\end{array}$ & & & & & & & & 1 & -.001 & -.149 & -.048 & -.033 & .008 & .089 & .060 & $.210^{* *}$ \\
\hline $\begin{array}{l}(9) \\
\text { FUNT_CAC }\end{array}$ & & & & & & & & & 1 & .098 & $.198^{*}$ & -.094 & -.104 & .030 & -.050 & $-.202 *$ \\
\hline $\begin{array}{l}(10) \\
\text { ETHN_CEO }\end{array}$ & & & & & & & & & & 1 & .140 & -.029 & -.089 & $-.180^{*}$ & .055 & $-254^{* *}$ \\
\hline $\begin{array}{l}(11) \\
\text { ETHN_CAC }\end{array}$ & & & & & & & & & & & 1 & .080 & -.072 & -.121 & .056 & -.008 \\
\hline (12) SIZE & & & & & & & & & & & & & 1 & .065 & $.183^{*}$ & .075 \\
\hline (13) LEV & & & & & & & & & & & & & & & $-.215^{* *}$ & .101 \\
\hline (14) BIG4 & & & & & & & & & & & & & & & 1 & .081 \\
\hline (15) INDS & & & & & & & & & & & & & & & & \\
\hline
\end{tabular}

Notes: * indicates significance level at 0.05 level, ** indicates significance level at 0.01 level. 
In sum, the majority of results show negative relationships between variables. Therefore, it can be presumed that the internal factors that are the characteristics of CEOs and CACs do not have a significant influence on the incidents of financial restatements.

The Effect of Managers' Characteristics on Financial Restatements Controlling Other Factors

Table 4 illustrates the logistic regression results, which comprises of all variables; demographic profile of CEOs and CACs, company size, leverage, and auditor type and industry classifications. From all of the eleven hypotheses, only two variables show significant results; $\mathrm{p}<0.05$ and $\mathrm{p}<0.01$, respectively. The two variables are education of CEOs $(p=0.043)$ and functional tracks of CEO $(p=0.011)$.

With respect to educational background, there is a significant positive relationship between financial restatements and education of CEOs. This finding indicates highly educated CEOs are likely to restate company's earnings if there are motivations for them to do such activities and practices (Rosner, 2003). In relation to functional track, it appears that there is a significant negative relationship between functional tracks of CEOs and financial restatements. It shows that the existence of financial restatements does not reflect the functional background of CEOs. As in the descriptive statistic, most of the CEOs are in the throughput functions. Therefore, the result is not in line with the H2a, indicating inconsistent with prior studies.

Table 4

Logistic Regression Analysis Result

\begin{tabular}{|c|c|c|c|c|c|c|c|c|}
\hline & & & & & & & 95\% C.I. & EXP(B) \\
\hline & B & S.E. & Wald & $\mathrm{df}$ & Sig. & $\operatorname{Exp}(B)$ & Lower & Upper \\
\hline AGE_CEO & -.030 & .023 & 1.629 & 1 & .202 & .971 & .928 & 1.016 \\
\hline AGE_CAC & .008 & .019 & .155 & 1 & .694 & 1.008 & .970 & 1.047 \\
\hline TENURE_CEO & -.032 & .025 & 1.665 & 1 & .197 & .968 & .922 & 1.017 \\
\hline TENURE_CAC & $\begin{array}{l}.007 \\
\end{array}$ & .040 & .030 & 1 & .863 & .993 & .918 & 1.075 \\
\hline EDU_CEO & .294 & .145 & 4.113 & 1 & .043 & 1.342 & 1.010 & 1.782 \\
\hline EDU_CAC & -.106 & .138 & .588 & 1 & .443 & .900 & .687 & 1.179 \\
\hline FUNT_CEO & .949 & .373 & 6.471 & 1 & .011 & 2.583 & 1.243 & 5.365 \\
\hline FUNT_CAC & .082 & .449 & .033 & 1 & .856 & 1.085 & .450 & 2.617 \\
\hline ETHN_CEO & .138 & .253 & .296 & 1 & .586 & 1.148 & .699 & 1.885 \\
\hline ETHN_CAC & -.142 & .307 & .213 & 1 & .644 & .868 & .476 & 1.584 \\
\hline SIZE & -.443 & .407 & 1.188 & 1 & .276 & .642 & 289 & 1.425 \\
\hline LEV & .555 & .677 & .672 & 1 & .412 & 1.742 & .462 & 6.573 \\
\hline BIG4 & .064 & .384 & .028 & 1 & .868 & 1.066 & .502 & 2.264 \\
\hline INDS & -.076 & .107 & .512 & 1 & .474 & .926 & .752 & 1.142 \\
\hline Constant & -1.053 & 2.214 & .226 & 1 & .634 & .349 & & \\
\hline $\mathrm{R}^{2}$ & & & & & & & & \\
\hline Adjusted $\mathrm{R}^{2}$ & & & & & & & & \\
\hline Hosmer and Leme & st $=$ & & & & & & & \\
\hline Overall case correc & ted & & & & & & & \\
\hline
\end{tabular}

The prior studies suggest that a manager with the output function appears as a risk taker and they tend to involve in financial restatement as this practice often associates with the risk and uncertainty (Gupta 1984; Ali \& Taylor, 2014). In addition, prior findings indicate that a throughput manager seems to be more conservative in terms of strategies taken and level of tolerance for the uncertainty (Bamber, Jiang, \& Wang, 2010). Since the results of functional tracks' characteristics do not support the hypothesis and 
inconsistent with previous studies, apparently, it is possible for throughput managers to engage in financial restatement activities, as they possess the finance and accounting knowledge. In relation to educational background, the knowledge certainly benefits managers in such a way of which accounting method and approach should be taken for the purpose of firm's betterment.

\section{CONCLUSION}

In general, the objective of this study includes the examining the effect of managers' characteristics on financial restatements. The results in this study show that not all features of CEO influence financial restatements. Only two variables affect the restatements, which are the educational and functional background. It appears that the education level of CEO has a significant positive relationship with restatements. In other words, highly educated CEOs are likely to restate company's earnings if there are motivations for them to do such practices (Rosenr, 2003). In relation to the functional track of CEO, it appears that the functional background has a significant negative relationship with financial restatements. Such findings indicate that regardless of the CEO's functions either output or throughput, the events of financial restatements is still happening among public listed firms. The findings in this study imply that company's boards concerned with a true and fair view financial statement should consider the significance of recruiting top managers with higher education level and with throughput functional track. In other words, the recruitment of top managers should be done thoroughly as these managers are having massive experience in accounting and finance.

This study is not without limitations. First, there may be other internal factors that may affect financial restatements but are not included in this study, such as, chief financial officer characteristics and audit committee characteristics. Second, the results of this study could not be generalised to other developing countries that have a different ownership structure and regulations. Third, this study does not differentiate between intentional and unintentional financial restatements as this study assumed that all restatements are in an equal form. Further, research on this issue could be undertaken in the future, such as to examine in depth the nature of restatements in the annual reports or quarterly financial reports.

\section{ACKNOWLEDGEMENT}

We wish to thank Accounting Research Institute and Universiti Teknologi MARA for the financial support in making this study a success.

\section{REFERENCES}

Abdullah, S.N., \& Mohd Nasir, N. (2010). Financial restatements and corporate governance among Malaysian listed firms. Managerial Auditing Journal, 25(6), 526-552.

Ali, M.M., \& Taylor, D. (2014). Corporate risk disclosure in Malaysia: The influence of predispositions of Chief Executive Officers and Chairs of Audit Committee. Research Journal of Finance and Accounting, 5(2), 92-106.

Anderson, K.L., \& Yohn, T.L. (2002). The effect of 10-K restatements on firm value, information asymmetries, and investors' reliance on earnings. Georgetown University, Washington, DC.

Arthaud-Day, M.L., Certo, S.T., Dalton, C.M., \& Dalton, R. (2006). A changing of the guard: executive and director turnover following corporate financial restatements. Academy of Management Journal, 49, 1119-1136.

Ball, R., Robin, A., \& Wu, J.S., (2013). Incentives versus standards: properties of accounting income in four East Asian countries. Journal of Accounting and Economics, 36, 235-270.

Bamber, L.S., Jiang, J., \& Wang, I. Y. (2010). What's my style? The influence of top managers on voluntary corporate financial disclosure. The Accounting Review, 85(4), 1131-1162. 
Brick, I.E., Palmon, O., \& Wald, J.K. (2006). CEO compensation, director compensation, and firm performance: Evidence of cronyism?. Journal of Corporate Finance, 12, 403-423.

Carlsson, G., \& Karlsson, K. (1970). Age, cohorts and generation of generations. American Sociological Review, 35, 710718.

Child, J. (1974). Managerial and organizational factors associated with company performance. Journal of Management Studies, 11, 13-27.

Collins, O., \& Moore, D.G., (1970). The organization makers. New York: Appleton Century Crofts.

GAO (2001). Financial Restatement Database. Report 06-1053R. Government Printing Office, Washington, DC.

GAO (2002). Financial statement restatement: trends, market impacts, regulatory responses and remaining challenges, Report to the Chairman, Committee on Banking, Housing, and Urban Affairs, US Senate, Report, Government Printing Office, Washington, DC, 38-101.

Gray.D. (1998). Towards a theory of cultural influence on the development of accounting systems internationally. Abacus, 24(1), 1-15.

Gupta, A.K. (1984). Contingency linkages between strategy and general manager characteristics: a conceptual examination. Academy of Management Review, 9(3), 399-412.

Hambrick, D.C. (2007). Upper Echelons Theory: An Update. Academy of Management Review, 32(2), 334-343.

Hambrick, D.C., \& Fukutomi G.D.S. (1991). The seasons of a CEO’s tenure. Academy of Management Review, 16(4), 719-742.

Hambrick, D.C., \& Mason, P.A. (1984). Upper Echelons: The organization as a reflection of its top managers. Academy of Management Review, 9(2), 193-206.

Haniffa, R.M., \& Cooke, T.E. (2005). The impact of culture and governance on corporate social reporting, Journal of Accounting and Public Policy, 24, 391-430.

Hart, P., \& Mellon, J. (1970). Management youth and company growth; a correlation?. Management decision, 4(2), 5053.

Hasnan, S., Abdul Rahman, R., \& Mahenthrian, S. (2008). Management predisposition, motive, opportunity, and earnings management for fraudulent financial reporting in Malaysia. Working paper, pp.30. Retrieved from www.ssrn.com.

Hofstede, G. (1980). Culture and organizations. International Studies of Management and Organization, 10(4), 15-41.

Layton, R.A. (2008). The Search for a dominant Logic: A macro-marketing Perspective. Journal of Macro-marketing, 28(3), 215-227.

Luo, X, Kanuri, V.K., \& Andrews, M. (2013). How does CEO tenure? The mediating role of firm-employee and firm-customer relationships. Strategic Management Journal, 1-20.

Ma. (2011). Research on impact of financial restatement on firm value in Chinese Listed Firms. Retrieved from http://papers.ssrn.com/sol3/papers.cfm?abstract id=1870971

Miller, D., \& Shamsie J. (2001). Learning across the life cycle: experimentation and performance among the Hollywood studio heads, Strategic Management Journal, 22(8), 725-745.

Okwo, I.M., Ugwunta, D.O., \& Nweze, A.U. (2012). Investment in fixed assets and firm profitability: Evidence from the Nigerian brewery industry. European Journal of Business and Management, 4(20), 10-17.

Plumlee, M., \& Yohn, T.L. (2010). An Analysis of the Underlying Causes Attributed to Restatements. Accounting Horizons, 24(1), 41-64.

Rosner, R.L. (2003). Earnings manipulation in failing firms. Contemporary Accounting Research, 20(2), 361-408. 